International Journal of Engineering \& Technology, $7(3.2)(2018) 636-641$
International Journal of Engineering \& Technology
SPC
Website: www.sciencepubco.com/index.php/IJET
Research paper

\title{
Soil Compaction Methods Development
}

\author{
Tetyana Lvovska ${ }^{1}$, Tetyana Lytvynenko ${ }^{2}$, Alla Kariuk ${ }^{3}$ \\ ${ }^{I}$ Poltava National Technical Yuri Kondratyuk University, Ukraine \\ ${ }^{2}$ Poltava National Technical Yuri Kondratyuk University, Ukraine \\ ${ }^{3}$ Poltava National Technical Yuri Kondratyuk University, Ukraine \\ *Corresponding author E-mail: lvovska.tetiana@ukr.net
}

\begin{abstract}
A process of soil compaction methods development including new authors' methodology is described. The importance of soil compaction for engineering purposes is substantiated. Preconditions for Proctor compaction test appearance are highlighted. Proctor's approach and suggestions for the degree of soil compaction assessing are analyzed. Soviet version of Proctor's equipment and Modified Proctor compaction test are given. Principal differences between Proctor test, Standard compaction test and Modified Proctor test are presented. The problems and disadvantages of existent soil compaction tests are revealed. New authors' physical experiment methodology for patterns establishment of water migration in subgrade embankment depth, in the capacity factors of what it is accepted: clay soil type (its number plasticity); moisture, at what the soil was compacted; soil skeleton density; embankment height; «rest» time after subgrade erection and before it's operation is developed and realized. By laboratory and field tests water migration patterns in compacted subgrade soils depth are established. As a result of statistical processing of research results, the empirical dependence of compacted clay soil stabilized moisture is obtained. Empirical dependence parameter corresponds to maximum molecular moisture capacity at what it is advisable to do the subgrade clay soils multilayer consolidation for their long-term strength ensuring.
\end{abstract}

Keywords: long-term strength ensuring, modified Proctor test, molecular moisture capacity (maximum quantity of unfree water), standard density method, standard Proctor test.

\section{Introduction}

Compaction of soils has been used to improve its properties for as long as mankind had the need to provide pathways for carrying meaningful traffic volumes irrespective of whether the traffic volumes were pedestrians, animal or motorised vehicles. Although it can be accepted that the early road builders did not understand the principles of soil mechanics, they knew intuitively (and empirically) that if a heavy load was applied to the soil, its characteristics improved in a way that it provided a more mechanically stable pathway, more suitable for their purposes.

Soil compaction is widely applied in geotechnical engineering practice. It is used to maximise the dry density of soils to reduce subsequent settlement under working loads or to reduce the permeability of soils. The durability and stability of structures are highly related to the appropriate compaction achievement. The structural failure of roads and airfields, and the damage caused by foundation settlement can often be traced back to the failure in achieving adequate compaction. For that reason, soil compaction is important for engineering activities involving earthworks. The need for proper compaction became crucial during the early $20^{\text {th }}$ century, as a result of increased traffic and axle loads. A wide range of different types of compaction equipment was developed during the $20^{\text {th }}$ century, with vibratory compaction that was gaining rapidly due to road pavement layers compaction importance [1]. The development of compaction equipment and techniques is still continuing today in order to further improve compaction, as it is one of the most important factors determining the performance of road pavement structures.

\section{Preconditions for Proctor Compaction Test Appearance}

In the USA, embankments began to be compacted layer by layer from 1925 to increase strength, reduce water permeability and subsequent soil's settlement. However, the requirements for the degree of soil compaction were not formulated by this time. Therefore, when near Los Angeles the flood washed out the earth bank (Fig.1), there was no one to lay a claim to the low work quality - there were no criteria for the compaction quality [2].

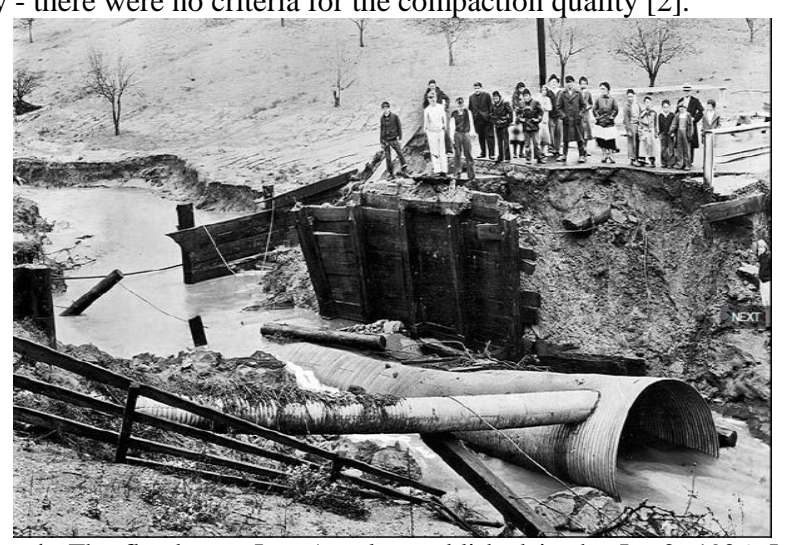

Fig. 1: The flood near Los Angeles, published in the Jan.2, 1926, Los Angeles Times 
In response to these conditions, field engineer of the Los Angeles water service, R. R. Proctor, in 1933 offered a method for degree of soil compaction evaluating and published several articles on this topic in the journal «Engineering News Record». Fundamental principles of this method have been preserved in modern normative methods for the degree of soil compaction assessing taken in different countries, including Ukraine.

The degree of possible soil compaction, first of all, depends on particles distribution in size and shape: if it contains both large and small grains, placed inside the pores between the coarse, the possible density increases. The greater mechanical work applied to the compaction, the higher soil density is achieved. Finally, with the same expended work on the given soil compaction, the resulting density depends on soil moisture content during compaction. The combined influence of these factors makes it difficult to assess the degree of compaction. On Proctor's suggestion, for each soil, first in laboratory conditions, with the same for all soils compaction work, reveals the density to which it should strive to compact it in the field, and then measure density indicator, obtained in the field, and compare it with obtained in the laboratory. Proctor offered to use not density (moist) soil $\rho=\mathrm{M} / \mathrm{V}$ (mass per unit volume of soil) for evaluation, but the so-called soil skeleton density $\rho_{d}$ - is the mass of solid particles in the unit volume of soil (in English - dry density - hence the index d). This is fundamentally important. In fact, the purpose of compaction is to bring soil coarse grains between them so that they form a system that is well aware of the external load [3-5].

The greater grains mass in a given soil volume, the closer grains arranged and the better soil rolling. The soil mass $\mathrm{M}$ consists of the particles mass $\mathrm{Ms}$ and water mass $\mathrm{Mw}$, and the air-bubble voids mass $\mathrm{Ma}$ is negligible: $\mathrm{M}=\mathrm{Ms}+\mathrm{Mw}$. Dividing both sides of this equation on the soil volume $\mathrm{V}$, we obtain $\rho=\rho_{\mathrm{d}} \bullet(1+\mathrm{w})$, where $\mathrm{w}=\mathrm{Mw} / \mathrm{Ms}$ is the moisture equal to the ratio of the water mass to the particles mass. Hence, after selecting a soil sample of a certain volume and weighing it, we can find the soil density $\rho=\mathrm{M} / \mathrm{V}$. Then, after drying to a constant weight, its moisture is found and the soil skeleton density is calculated from the formula

$$
\rho_{d}=\frac{\rho}{(1+W)}
$$

This formula is invariably used for all degree of compaction controlling methods. The procedure of Proctor laboratory test is that the soil is compacted by blows of the falling weight in a metal beaker at different moistures and optimum moisture is finded and corresponding to it maximum soil skeleton density at the standard compaction [4, 5]. The equipment used at Proctor test, the scheme of Standard and Modified Proctor tests and curves, obtained at both tests are shown in Fig.2, Fig. 3 and Fig. 4 correspondingly.

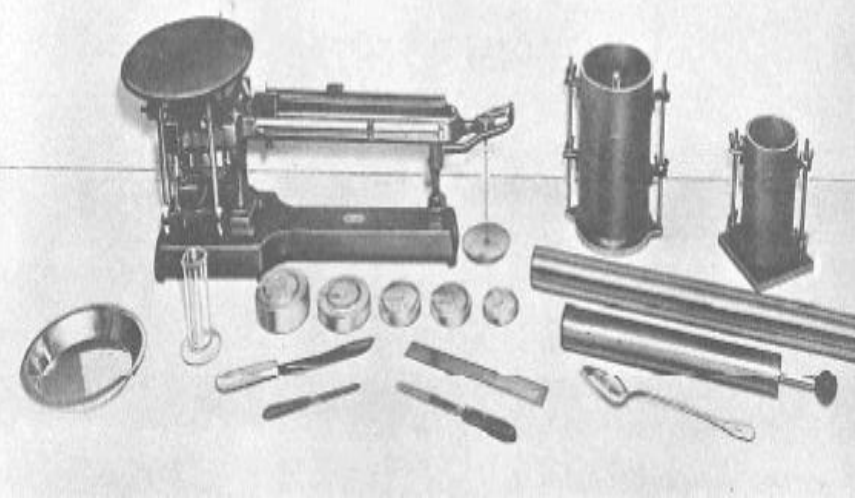

Fig. 2: The equipment for Proctor test

\section{Soviet Version of Proctor's Equipment}

In 1939, the road scientists N.N. Ivanov and M.Ya. Telegin created a Soviet version of Proctor's instrument, calling their version "Standard compaction" equipment. (The results obtained in both equipments are the same). The highest density, obtained in this instrument was called the "Standard density" [2, 4].

However, the maximum density obtained in the "Standard compaction", is not the maximum density for this soil. This was reminded by prof. N.N. Ivanov, one of the Proctor equipment Soviet version creator. If, as prof. Ivanov mentioned, to increase the plummet weight (for example, up to $4.5 \mathrm{~kg}$ ), the height of its dumping (for example, up to $42 \mathrm{~cm}$ ), as well as the number of discharges (for example, up to 40), it is obvious that the density, obtained in the equipment will be larger.

\section{4. "Modified Proctor" Compaction Test}

So did the American road workers, when after the 2nd World War the rate of motion and weight-carrying capacity increased. They developed a modification of Proctor's equipment, considering changes. The instrument was named "Modified Proctor" [5-7].

The highest soil density in "Modified Proctor" differs from density obtained in the usual "Proctor instrument", as well as from the highest density in the "Standard compaction" instrument by exactly 5\%. The compaction curve, obtained at Modified Proctor test versus Standard Proctor test is presented in Fig.2 [7, 8].

The principle difference between Standard compaction test, Proctor test and Modified Proctor test are shown in Tab. 1.

Table 1: Principle difference between Standard compaction test, Proctor test and Modified Proctor compaction test

\begin{tabular}{|c|c|c|c|c|c|c|c|}
\hline Characteristics & $\begin{array}{l}\text { Standard compac- } \\
\text { tion test }\end{array}$ & \multicolumn{3}{|c|}{ Proctor test } & \multicolumn{3}{|c|}{$\begin{array}{c}\text { Modified Proctor } \\
\text { test }\end{array}$} \\
\hline $\begin{array}{l}\text { Hammer } \\
\text { weight, } \\
\mathrm{mm}\end{array}$ & 127.4 & 120 & 125 & 200 & 120 & 125 & 200 \\
\hline $\begin{array}{l}\text { Hammer } \\
\text { diameter, } \\
\mathrm{cm}\end{array}$ & 10 & 10 & 15 & 25 & 10 & 15 & 25 \\
\hline $\begin{array}{l}\text { Drop } \\
\text { weight } \\
\text { mass, kg }\end{array}$ & 2.5 & 2.5 & 4.5 & 15 & 4.5 & 4.5 & 15 \\
\hline $\begin{array}{l}\text { Drop } \\
\text { weight } \\
\text { height of } \\
\text { fall , cm }\end{array}$ & 30 & 30 & 4.5 & 60 & 30 & 45 & 60 \\
\hline $\begin{array}{l}\text { Thickness } \\
\text { of a layer } \\
\text { packed up } \\
\text { at one } \\
\text { time, cm }\end{array}$ & $5-6$ & - & - & - & - & - & - \\
\hline $\begin{array}{l}\text { Number } \\
\text { of soil } \\
\text { layers }\end{array}$ & 3 & 3 & 3 & 3 & 5 & 5 & 3 \\
\hline $\begin{array}{l}\text { Number } \\
\text { of ham- } \\
\text { mer blows } \\
\text { per layer }\end{array}$ & 40 & 25 & 22 & 22 & 25 & 59 & 98 \\
\hline $\begin{array}{l}\text { Total } \\
\text { blows } \\
\text { amount }\end{array}$ & 120 & 75 & 66 & 66 & 125 & 295 & 294 \\
\hline $\begin{array}{l}\text { Stamp } \\
\text { diameter, } \\
\mathrm{mm}\end{array}$ & 100 & 50 & 75 & 75 & 50 & 75 & 125 \\
\hline $\begin{array}{l}\text { Energy } \\
\text { imparted } \\
\text { from } \\
\text { hammer } \\
\text { for each } \\
\text { sample }\end{array}$ & - & 0.6 & 0.6 & 0.6 & 2.7 & 2.7 & 2.7 \\
\hline
\end{tabular}

sample 

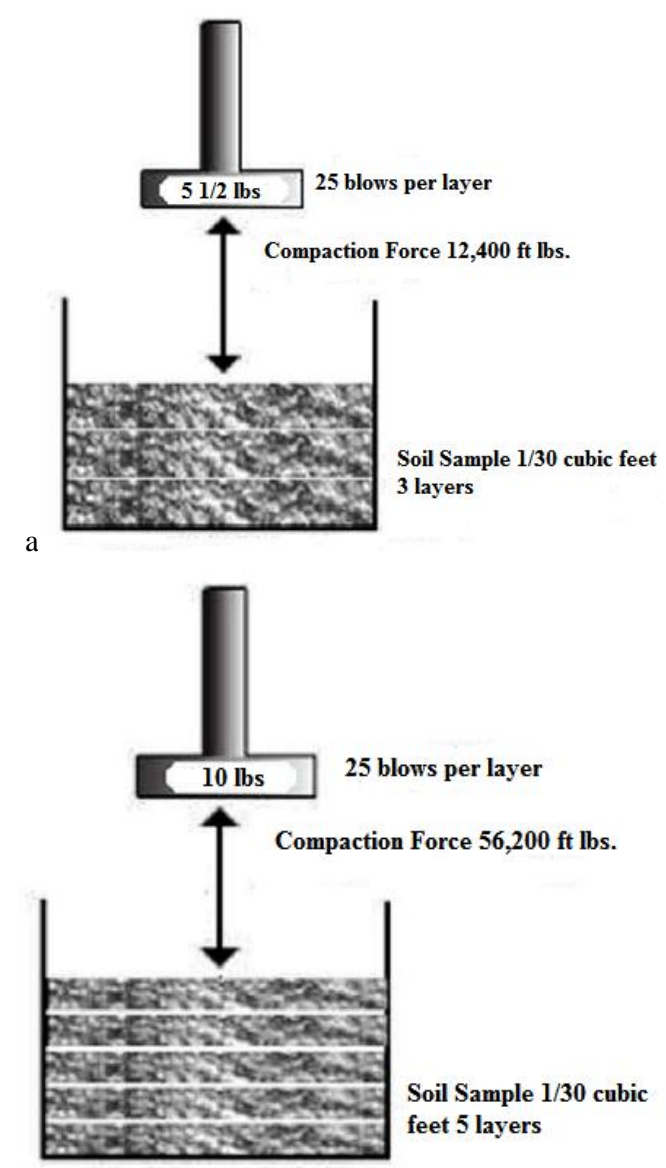

Fig. 3: AASHO tests:

a - Standard Proctor;

b - Modified Proctor

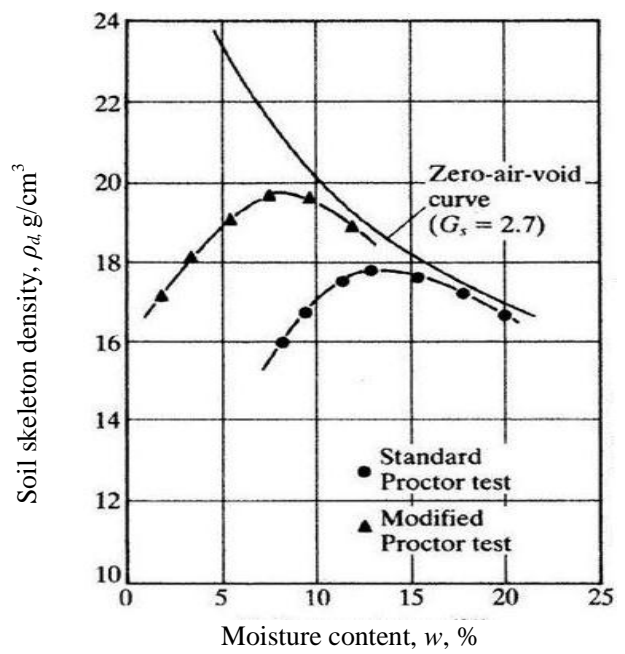

Fig. 4: The comparison of compaction curves between Standard and Modified Proctor compaction test

Also prof. Pavlyuk in his work [4] presented the comparison of compaction curves obtained at Proctor test and Standard compaction test (Fig. 5) and comparison of compaction curves obtained at Modified Proctor test and Standard compaction test (Fig. 6).

Maximum soil density is obtained at Modified Proctor test -1.94 $\mathrm{g} / \mathrm{cm}^{3}$, minimum soil density value at Standard compaction test $1.83 \mathrm{~g} / \mathrm{cm}^{3}$, and $1.86 \mathrm{~g} / \mathrm{cm}^{3}$ at Proctor test according to prof. Pavliuk research.

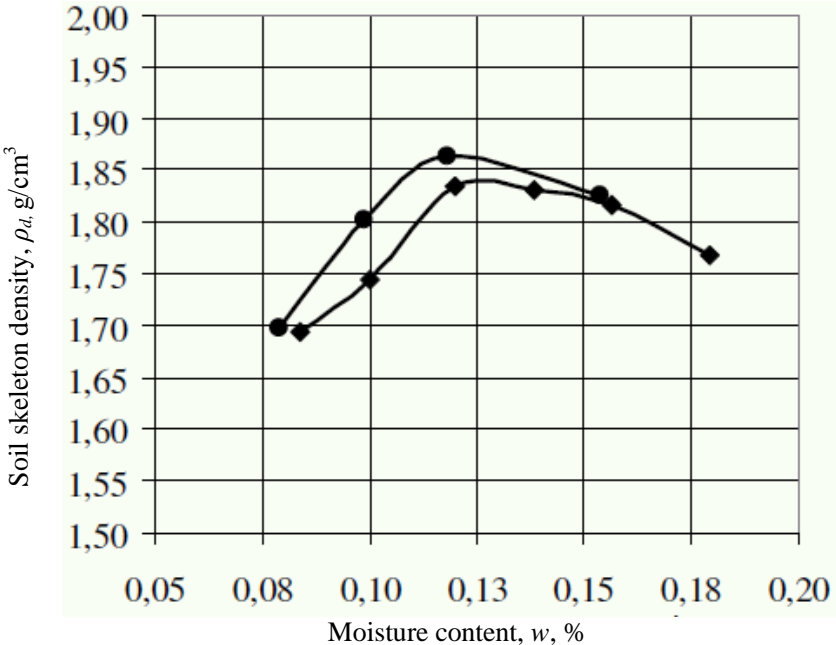

Fig. 4: The comparison of compaction curves between Proctor test (domed marker curve) and Standard compaction test (rhombus curve)

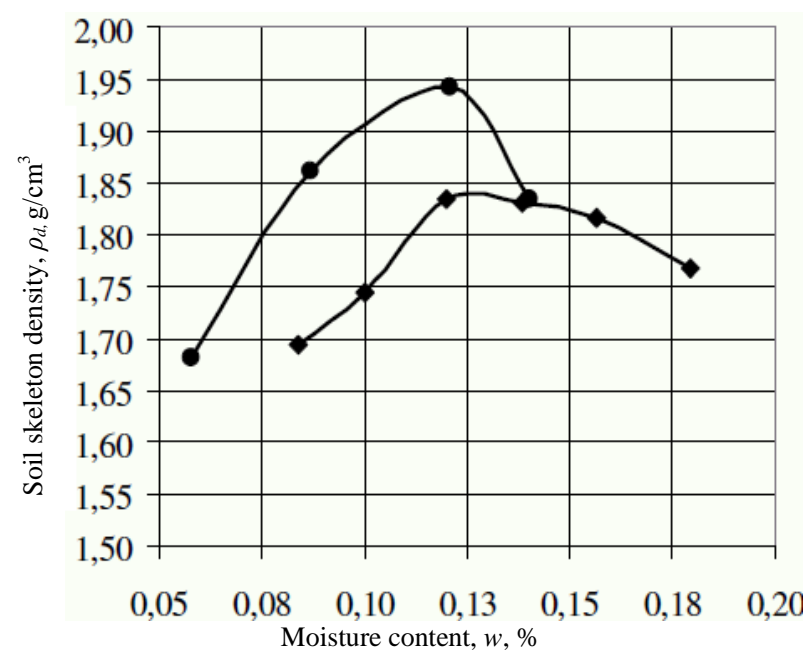

Fig. 5: The comparison of compaction curves between Modified Proctor test (domed marker curve) and Standard compaction test (rhombus curve)

\section{The New Approach in Soil Compaction Re- search}

However, the main problem in soil compaction is that domestic regulations prescribe optimal parameters of compacted clay soil (maximum soil skeleton density $\rho_{d \max }$ and optimum moisture content $W_{\text {opt }}$ ), based on the obtained values of laboratory conditions for a particular soil type and dynamic load characteristics without actual mechanisms characteristics [9].

When soil compacts due to high moisture, with a degree of saturation close to $S_{r}=1.0$, then, of course, the soil dries and held its sedimentation and therefore additional deformations, when soil compacts due to low moisture, it will be difficult to do the compaction, by the way, it's a little probability of desired soil skeleton density achieving, even with the modern mechanisms possibilities. Also national standards recommend for optimum clay soils moisture content, at the compaction by roller, to take plastic limit $W_{p}$, but this parameter is not related on how much unfree water the soil is actually containing [9]. That's why for subgrade erection long-term strength ensuring is important, i. e., when during normative operational time the values of soil mechanical characteristics, obtained after compaction, have been saved and excess soil's deformation doesn't appear.

The disadvantages of existent soil compaction methods are: the necessity to «bind» the soil compaction curve to specific compaction mechanism certain parameters; sufficiently wide boundaries of optimum soil moisture; some subjectivity in soil plastic limit determining and and so forth. So, the most common today concept in road soil compaction construction solves mainly the technologi- 
cal side of problem - the maximum soil skeleton density at fewest mechanism passage by one trough.

For the reliable subgrade operation it's necessary not only to achieve maximum multilayer consolidation values of its soil skeleton density and soil strength, but also to save them during normative time. On the embankment soils condition over time significantly affects moisture, at what the compaction was done and the particular water type split in compacted soil $[9,10]$. But it is still not researched quantitative impact on moisture conditions patterns in road embankment clay soils depth the next factors: soil skeleton density; compacted embankment height; the number of days, when compacted clay embankment «rests» after its erection, and before the operation.

In soil mechanics, minimum stress at what the soil sample is destroyed due to aeonic span of time, is accepted as long-term strength limit. Stress, at what the soil sample is destroyed due to certain period of time after load imposing as a result of unchangeable soil flow and advance flow of ground, corresponds to the soil long-term strength. So the theory considers revising that the most favorable conditions for the subgrade clay soils long-term strength ensuring and in accordance minimum ground distortion during specified time operation is to compact the soil in layers at moisture, close to maximum molecular moisture capacity $[9,10]$.

For new road embankment soils optimal compaction criteria substantiation with a purpose to ensure subgrade clay soil long-term strength, the new physical experiment methodology for water migration patterns establishment in subgrade embankment depth is developed, the capacity factors of what were accepted:

- clay soil type (its number plasticity $\mathrm{I}_{\mathrm{p}}$ );

- moisture, at what the soil was compacted;

- soil skeleton density in the embankment;

- embankment height;

- «rest» time after subgrade erection and before it's operation.

For its realization the equipment of Geotechnics department was used, where in 2013 - 2016 years the water migration patterns heightwise through the time in soil, placed in plastic tubes (it is simulated the soil multilayer consolidation of subgrade embankment). Research soil condition and type are changeable parameter. At the unifactor experiment two typical for compacted subgrade erection clay soils - heavy silt loam and light silt loam were used. The detail experiment description is presented in author's monography [9]. The soil was moved in pipes and uniform compacted using hand tamper with certain marks by its height (Fig. 6, a) all time to thickness of $30 \mathrm{~mm}$, and then pipe link (150 $\mathrm{mm}$ ) was connected to a total height (Fig. 6, b).

These pipes with compacted in layers soil were installed on a metal vertical frame. The lower pipe ends was installed in drainage channel, filled with stone screening dust (stone chips). Thus, free (gravity) water is able to migrate at all soil pipe height, what imitate it's migration within road embankment depth. The top of all pipes with compacted soil layers was hermetically closed to avoid evaporation of water «up». Then pipes were left on vertical frame alone, for the «rest».

After allowed time «rest» all pipes were dismantled into separate links. From each link it was selected at least two soil sample in bottles, and by normative weight method the final (stabilized) moisture of compacted soil was determined. So, within the laboratory experiment it was done:

-4 experiment series for relation of final soil moisture №1 from soil skeleton density $\rho_{\mathrm{d}}=1.50-1.65 \mathrm{~g} / \mathrm{cm}^{3}$ at pipe height $150 \mathrm{~cm}$ substantiation;

-4 analogous test series with research soil №2 at $\rho_{\mathrm{d}}=1.50-1.65$ $\mathrm{g} / \mathrm{cm}^{3}$ and pipe height $150 \mathrm{~cm}$;

- 5 experiment series for relation of final soil moisture №2 depending on pipe height $45,90,150,210$ and $285 \mathrm{~cm}$ and $\rho_{\mathrm{d}}=1.55$ $\mathrm{g} / \mathrm{cm}^{3}$;

- 3 test series for relation of final soil moisture №2 depending on waiting time 74,120 and 180 days at $\rho_{\mathrm{d}}=1.55 \mathrm{~g} / \mathrm{cm}^{3}$ revealing;

- 2 experiment series for relation of final soil moisture №2 from soil skeleton density $\rho_{d}=1.60 \mathrm{~g} / \mathrm{cm}^{3}$ and pipe height $150 \mathrm{~cm}$ at placement water content changing and probable capillary ascension of water.

The exact maximum molecular moisture capacity values was determined in laboratory conditions by moisture-holding capacity surroundings method.
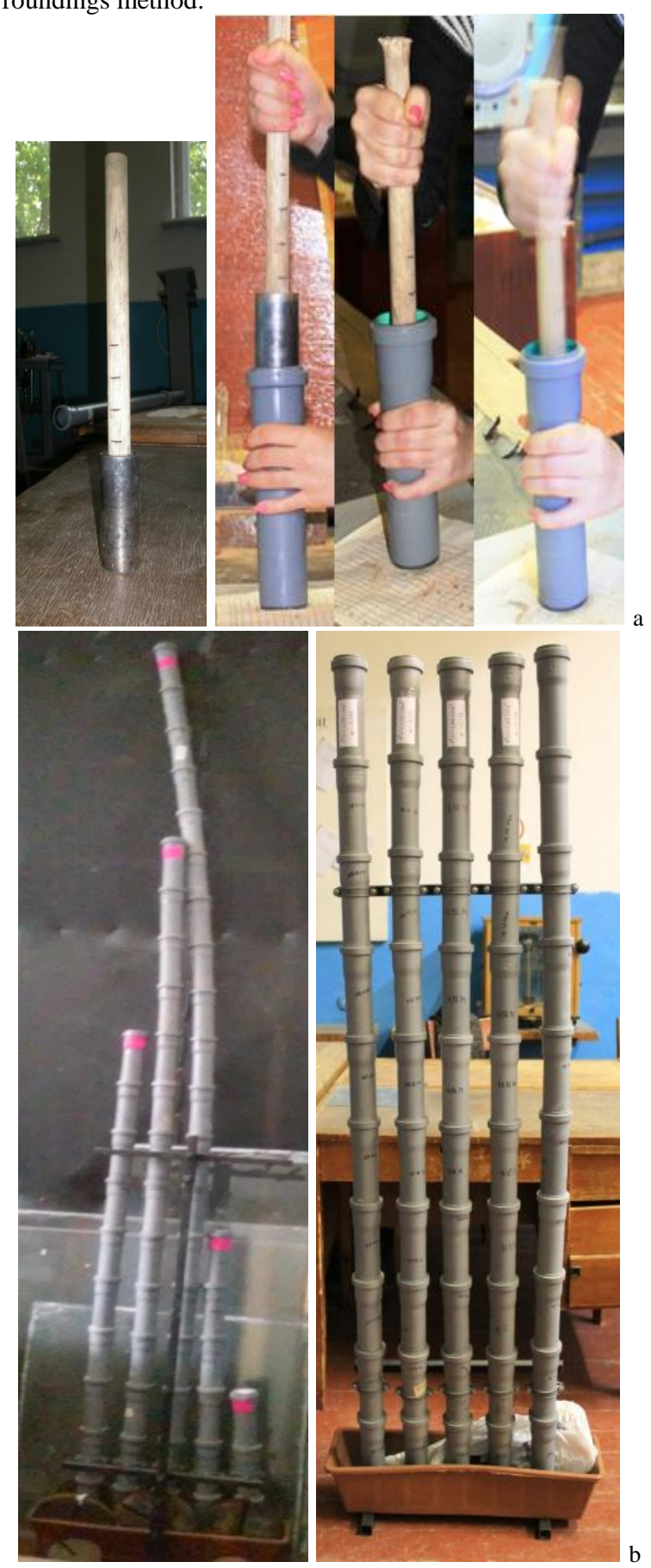

Fig. 6: The equipment used at new author's methodology: a - hand tamper with certain marks by its height;

$\mathrm{b}$ - pipes, gathered to a general height

The dependings graphs of compacted loam moisture was drawn and shown in [9].

The value of stabilized moisture generally corresponds to maximum molecular moisture capacity, at what it is advisable to do the subgrade clay soils multilayer consolidation for their long-term strength ensuring. So from the perspective of clay soil long-term strength ensuring just that parameter it is viable to accept as optimum moisture content $\mathrm{W}_{\text {opt }}$ of soil compaction.

The average results of compacted clay soil stabilized moisture are determined by whole pipe height, except it's upper and lower links for each preset soil skeleton value $\rho_{\mathrm{d}}=1.50-1.65 \mathrm{~g} / \mathrm{cm} 3$ placed in Tab. 2 and Tab. 3. 
Table 2: Average of final moisture $w_{k}$ of compacted heavy loam (research soil № 1) heightwise whole pipe

\begin{tabular}{|c|c|c|c|c|}
\hline $\begin{array}{l}\text { Preset soil } \\
\text { skeleton } \\
\text { density } \\
\rho_{d}, \mathrm{~g} / \mathrm{cm}^{3}\end{array}$ & $\begin{array}{l}\text { Corresponding } \\
\text { void volume } \\
\text { ratio, } e\end{array}$ & $\begin{array}{l}\text { Preset soil } \\
\text { moisture w } \\
\text { at } S_{r}= \\
0.85)\end{array}$ & $\begin{array}{l}\text { Final soil } \\
\text { moisture, } \\
w_{k}\end{array}$ & $\begin{array}{l}\text { Variation } \\
\text { coefficient } \\
w_{k}, v\end{array}$ \\
\hline 1.50 & 0.786 & 0.250 & 0.203 & 0.071 \\
\hline 1.55 & 0.729 & 0.231 & 0.190 & 0.068 \\
\hline 1.60 & 0.675 & 0.214 & 0.176 & 0.063 \\
\hline 1.65 & 0.624 & 0.198 & 0.167 & 0.065 \\
\hline
\end{tabular}

Table 3: Average of final moisture $w_{k}$ of compacted light loam (research soil № 2) heightwise whole pipe

\begin{tabular}{|c|c|c|c|c|}
\hline $\begin{array}{l}\text { Preset soil } \\
\text { skeleton } \\
\text { density } \\
\rho_{d}, \mathrm{~g} / \mathrm{cm}^{3}\end{array}$ & $\begin{array}{l}\text { Corresponding } \\
\text { void volume } \\
\text { ratio, } e\end{array}$ & $\begin{array}{l}\text { Preset soil } \\
\text { moisture } w \\
\left(\begin{array}{l}\text { at } S_{r}= \\
0.85)\end{array}\right.\end{array}$ & $\begin{array}{l}\text { Final soil } \\
\text { moisture, } \\
w_{k}\end{array}$ & $\begin{array}{l}\text { Variation } \\
\text { coefficient } \\
w_{k}, v\end{array}$ \\
\hline 1.50 & 0.786 & 0.250 & 0.162 & 0.072 \\
\hline 1.55 & 0.729 & 0.231 & 0.143 & 0.070 \\
\hline 1.60 & 0.675 & 0.214 & 0.130 & 0.072 \\
\hline 1.65 & 0.624 & 0.198 & 0.114 & 0.068 \\
\hline
\end{tabular}

In the last column of both tables the variation coefficient values of parameter is presented, by what the soil can be accepted as homogeneous.

By data of Tables 2 and 3 the dependings graphs (Fig. 7 a, b) are drawn:

- graph 1 - of soil moisture w, at what both research soils were compacted from soil skeleton density in road embankment (pipe);

- graph 2 - stabilized soil moisture of already compacted loams after subgrade «rest» time from within pipe height.
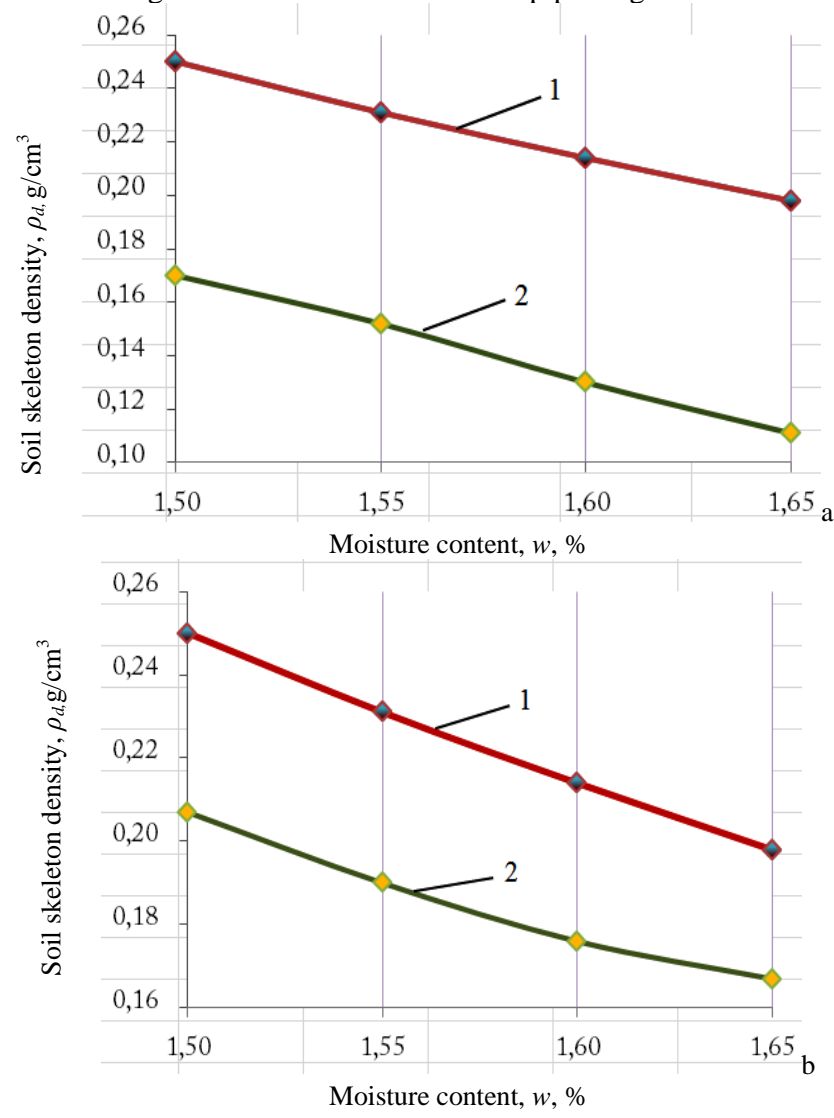

Fig. 2: Plots relation of soil moisture $w$ at what the loam was compacted, (1) and stabilized (final) soil moisture wk of already compacted heavy loam from after the «rest» time of subgrade (2) from soil skeleton density within pipe height: $\mathrm{a}$ - heavy loam; $\mathrm{b}$ - light loam

As a result of statistical processing by least squares method of research data Tab. 2 (and Fig. 7, a) it is found that the decreasing of stabilized moisture value $w_{k}$ of compacted heavy silty loam (research soil № 1) depending on the soil skeleton density growth within the experimental range $\rho_{d}=1.50-1.65 \mathrm{~g} / \mathrm{cm}^{3}$ it is most correctly to describe by logarithmic function of the form [9] $w_{k}=a+b \ln \left(\frac{\rho_{d}}{\rho_{d 0}}\right)$

where is $\rho_{d 0}=1 \mathrm{~g} / \mathrm{cm}^{3}$;

empirical coefficient is: $a=0.358 ; b=-0.384$.

At this multiple correlation coefficient $r$ and variation coefficient $v$ values in accordance is: $r=0.997 ; v=0.008$, what indicates about close relationship between the experimental data and about the correctness of their approximation by the logarithmic function [9].

Analogous logarithmic dependence is obtained also for stabilized moisture value $w_{k}$ of compacted light silty loam (research soil № 2). Empirical coefficient of equation (1) is: $a=0.362$; $b=-0.494$.

At this multiple correlation coefficient $r$ and variation coefficient $v$ values in accordance is: $r=0.998 ; v=0.0115$, what indicates about close relationship between the experimental data and about the correctness of their approximation by the logarithmic function [9].

Whereas road embankment height with compacted loam did not significantly affect its moisture conditions and subgrade «rest» time increasing after 2 months did not significantly affect the stabilized soil moisture value, for this reason, it is advisable to perform two-factor statistical analysis of compacted clay soil stabilized moisture depending on its soil skeleton density and plasticity index.

As a result of this statistical processing by least squares method the empirical dependence is obtained [9]

$w_{k}=a_{0}+a_{1}\left(\frac{\rho_{d}}{\rho_{d 0}}\right)+a_{2} \cdot I_{p}$

empirical coefficient is: $a_{0}=0.531 ; a_{1}=-0.279$; $a_{2}=0.570$.

At this multiple correlation coefficient is $r=0.995$, and Fisher's ratio test $F=106.326$, what more than its table-valued $F_{\text {табл }}=4.89$ at test significance $p=5 \%$ and the degree of freedom $v_{1}=7$ and $v_{2}=5$.

Statistical values indicate close relationship between the research data and therefore, about the logarithmic function (3) correctness.

The results of physical laboratory experiment related to quantitative patterns of water migration in compacted heavy and light silt loams (clay soils type - its plastic index $\mathrm{I}_{\mathrm{p}}$, soil skeleton density , $\mathrm{g} / \mathrm{cm}^{3}$, stabilized (final) moisture of compacted clay soil $\mathrm{w}_{\mathrm{k}}$ ) are presented in Tab. 4.

The Tab. 4, in particular, clearly shows that an increase of its plasticity number $I_{p}$ at the same soil skeleton density values, stabilized moisture of compacted clay soil $\mathrm{w}_{\mathrm{k}}$ increases.

Table 4: Stabilized moisture values of compacted heavy and light silty loams within pipe height for each preset subgrade soil skeleton density

\begin{tabular}{|c|l|l|}
\hline \multirow{2}{*}{$\begin{array}{c}\text { Preset soil skeleton density, } \\
\rho_{d}, \mathrm{~g} / \mathrm{cm}^{3}\end{array}$} & \multicolumn{2}{|c|}{ Soil plasticity number, $I_{p}$} \\
\cline { 2 - 3 } & 0,162 & 0,080 \\
\hline 1.50 & $\underline{0.203}$ & $\underline{0.162}$ \\
\hline \multirow{2}{*}{1.55} & $\underline{-0.95 \%}$ & $\underline{0.190}$ \\
\hline \multirow{2}{*}{1.60} & $\underline{-0.51 \%}$ & $\underline{0.143}$ \\
\hline \multirow{2}{*}{1.65} & $\underline{-0.86 \%}$ \\
\hline & $\underline{-0.58 \%}$ & $\underline{0.167}$ \\
\hline
\end{tabular}

Note: numerator - the experimental values of stabilized clay soil moisture wk; the denominator - the relative error of this parameter, calculated by the expression (3) 


\section{Conclusions}

1. Agreeably with standards maximum soil skeleton density $\rho_{\text {dmax }}$ and optimum moisture content $W_{\text {opt }}$, are prescribed from obtained for particular soil type and dynamic effect parameters without mechanism peculiarities considering. But the standarts do not correspond to machinery facilities, because with compaction energy per unit of volume increasing the optimum moisture content and maximum soil skeleton density values considerably change. By the full-scale experiment the theory for subgrade erection longterm strength ensuring and minimum deformations during its normative operational time, the soil multilayer consolidation should be done at moisture, close to maximum quantity of unfree water is approved.

2. As a result of statistical processing by least squares method the research laboratory and field data, the empirical dependence of compacted clay soil stabilized moisture for their multilayer consolidation in relation to soil skeleton density and plasticity number values is obtained. Empirical dependence parameter corresponds to maximum molecular moisture capacity at what it is advisable to do the subgrade clay soils multilayer consolidation for their longterm strength ensuring.

3. Clay soil embankment multilayer consolidation is desirable to do at moisture, that corresponds to maximum molecular moisture capacity, accepted by the expression (3) depending on soil skeleton density specified rate and plasticity number of this soil. The value of this moisture is lower than plastic limit, but present-day compacted machines makes it possible to sufficiently increase the specific compaction energy for the soil compaction at moisture less than plastic limit with a maximum soil skeleton density.

\section{Acknowledgement}

The authors would like to express their sincere gratitude to the colleague and onetime scientific advisor of one of the author Yu.Vynnykov, for his valuable advices and inspiration.

\section{References}

[1] K. Nurses, Compaction behaviour of soils, Monash University, Australia, 2011, 239 p.p., doi:10.4225/03/5890111BEEA19

[2] R.C. Karen, S. Landsburg, Soil Compaction and pipeline construction: A Literature Review, Research monograph (1990), Nova corporation of Alberta, Calgary, Alberta, 48., doi:10.7939/R3QV81

[3] Ribeiro E., Batjes N.H., World Soil Information Service (WoSIS) Towards the standardization and harmonization of world soil data. Procedures manual 2018, Report 2018/01, ISRIC - World Soil Information, Wageningen, doi:10.17027/ISRICWDCSOILS.20180001

[4] Pavlyuk D.O. Porivnyannya metodiv i zasobiv kontrolyu ushchil'nennya gruntiv pry budivnytstvi zemlyanoho polotna /

D.O. Pavlyuk, M.V. Shur"yakov, S.A. Hladun // Zb. nauk. prats' (Haluzeve mashynobud., bud-vo) / Polt. nats. tekhn. un-t im. Yuriya Kondratyuka. Vyp. 2(47). - Poltava: PoltNTU, 2016. - S. $233-245$

[5] A. Aboufayed, Soil moisture content in hill-filed side slope, International, Journal of Geological and Environmental Engineering, Vol.7, No.3, (2013), pp.147-151., doi:10.5281/ZENODO.1061638

[6] T.C. Hopkins, T.L. Beckham, L.Sun, Characteristics and engineeringp of the soft soil layer in highway soil subgrades, Research Report 2006/06, Kentucky Transportation Center, http://dx.doi.org/10.13023/KTC.RR.2006.13

[7] P. Schjønning, Case study soil compaction, available online: https://www.researchgate.net/publicaton/283573255_Case_study_s oil_compaction?channel=doi\&linkId=5640751d08ae8d65c0151fd6 \&showFulltext=true, last visit: 30.03.2018, doi 10.13140/RG.2.1.2994.3767

[8] N.Persaud, R.W. Zobel, Optimum sub-grade compaction levels for turf growth in constructed soil profiles, Technical Report 2009/05, doi: 10.13140/2.1.2621.2482

[9] Vynnykov Yu. Moisture conditions patterns in road embankment clay soils depth / Yu. Vynnykov, T. Lytvynenko // Energy and Environment: monografie, studia, rozprawy.M95
. - Under the general editorship Anatoliy M. Pavlenko. - Kielce: Wydawnictwo Politechnici Swietokrzyskiej. - 2017. - P. 132 - 155. - PL ISSN 1897-2691. PL ISBN 978-83-65719-195.

[10] Vynnykov Y.L. Investigation of Compacted Clay Embankment Stabilized Moisture / Y.L. Vynnykov, V.I. Kovalenko, T.V. Lytvynenko // Collection of scientific articles «Energy, Energy Saving and Rational Nature Use». - №2(3), 2014. - Kazimierz Pulaski University of Technology and Humanities in Radom, Poltava National Technical Yuri Kondratyuk University. - Radom, 2014. - P. $53-57$. 